\title{
Reflection of Corporate Social Responsibility Implementation: Community Engagement In Sustainability Aspects
}

\author{
Magdalena*; Eko Ganis Sukoharsono; Roekhudin \\ Faculty of Economics and Business, Brawijaya University, Indonesia \\ Email: 233012089@student.uksw.edu
}

http://dx.doi.org/10.18415/ijmmu.v5i5.526

\begin{abstract}
Social responsibility is a form of business commitment to continue acting ethical, operate legally in sustainable economic development to all stakeholders and the wider community. The aim of the study was to reflect on Corporate Social Responsibility at PT. BNI regarding Community Engagement? The research approach used is a qualitative approach. The interpretive paradigm is used by researchers so that they can assist researchers in achieving the objectives in carrying out research by reflecting the CSR of PT. PTI (Persero) Tbk. The primary data source in this study was through interviews with corporate and community CSR staff and direct observation to review the implementation of the PT.BNI CSR program. While secondary data sources are annual reports and sustainability reports (CSR). Researchers use the type of method content analysis guided by sustainability accounting author Sukoharsono. The results of the research on the implementation of CSR to the community through partnership and community development programs have a good impact on the welfare of the community which are examined based on 4 aspects, namely social, economic, environmental and spirituality.
\end{abstract}

Keywords: Orporate Social Responsibility; Community Engagement; Sustainability Accounting

\section{Introduction}

Today's business environment requires companies not only to pay attention to technical and financial factors in carrying out their business. Banks that are part of the company are required to be more open in expressing their social responsibilities as the business world continues to grow. Corporate social responsibility is a form of the company's commitment to build a better quality of life with relevant stakeholders, especially those around where the company is located. CSR is increasingly important role in encouraging the social responsibility of the vast corprate for the creation of balanced development in economic, social and environmental. The government is also very supportive of activities towards the implementation of CSR listed in the regulations relating to social responsibility in Indonesia is the Law No. 40 of the Limited Liability Company in 2007 concerning the obligation of companies to submit annual reports, one of which concerning corporate social and environmental responsibility.

Research by Moravcikova et al. (2015) focuses on the importance of CSR reports in communication as corporate social responsibility regarding company policies in relation to the 
environment, sustainability, and fulfillment of commitments to stakeholders. Given that environmental issues are increasingly closely related to companies, so not a few companies are competing to implement CSR as a form of responsibility for their company's activities. In the current development of CSR, researchers intend to highlight one financial institution as a research site. Previous research on CSR by using the concept of community engagement in corporate social responsibility reporting is possible to see how much the company is contributing to society. Communities have different local wisdom in each region, so corporate social responsibility programs must be adapted to the conditions of the local community (Lin et al., 2014).

The community is increasingly aware of the social impacts caused by the company in carrying out its operations. Therefore, the company must always pay attention to the social impacts caused by the company and try to overcome them. The implementation of the CSR program related to community engagement is an involvement that refers to public participation during organizational decision-making processes. Participation by community members in the form of assessment and planning. Public participation will be focused on the needs, expectations, and desires of community members. The research objective is to reflect CSR at PT. BNI regarding Community Engagement?

\section{Literature Review Corporate Social Responsibility}

CSR is a business commitment of a company to continue to act ethically, operate legally and contribute to sustainable economic development. The forms of CSR in the community are Corporate Philanthropy, Corporate Responsibility and Corporate Policy (Harahap., 2007). Corporate Philanthropy is the responsibility of the company to be limited to voluntary charity that has not arrived at obligation. Corporate Responsibility is a social responsibility that is part of the company's obligations, either because of the provisions of the Law or company awareness. Corporate Policy is a corporate social responsibility that is part of its policy.

\section{Community Engagement (CE)}

Community Engagement is a form of social responsibility carried out by business entities. CE can be created if the CSR program is run based on the company's goals, namely the welfare of its stakeholders. Stakeholders as parties or groups who have an interest both directly and indirectly, the existence of the company can influence and be influenced by the company (Wibisono., 2007). Stakeholders are parties inside and outside the company who have a role in determining the success of the company (Kasali., 2005).

\section{Theory Stakeholder}

Theory stakeholder says that the company is not the only entity that operates for its own account but must provide benefits to stakeholders. Thus, the existence of a company is strongly influenced by the support provided by stakeholders to the company (Ghozali and Chariri., 2007). The definition of stakeholders according to Freeman (1984) in Moir (2001) is any group or individual that can influence or be influenced by the achievement of organizational goals.

Kasali (2005) divides stakeholders into internal stakeholders and external stakeholders. Internal stakeholders are stakeholders who are within the organization, for example employees, managers and shareholders. While external stakeholders are stakeholders who are outside the organization's 
environment, such as: suppliers or suppliers, consumers or customers, the community, government, press, investor groups, and others. Primary stakeholders, secondary stakeholders and marginal stakeholders. Primary stakeholders are stakeholders that must be considered by the company, and secondary stakeholders are less important stakeholders, while marginal stakeholders are stakeholders who are often ignored by the company. Traditional stakeholders and future stakeholders. Employees and consumers are traditional stakeholders, because they are now associated with the organization. While future stakeholders are stakeholders in the future are expected to have an influence on the organization, such as: researchers, potential consumers, potential investors (potential investors) and others. Proponents, opponents, uncommitted. Stakeholders proponents are stakeholders that are pro-company, stakeholders opponents are stakeholders that are not company-side, while uncommitted stakeholders are stakeholders who no longer care about the company (organization) Silent majority and vocal minority. Seen by stakeholders' activities in making complaints or their support is vocal (active), but there are also those who state it silently (passively).

\section{AA1000 Stakeholder Engagement Standard}

In the AA1000 Framework Standard published in 1999, AccountAbility first introduced the principle of inclusiveness (AA1000 Stakeholder Engagement Standard., 2015). Inclusiveness is the participation of stakeholders in developing and achieving accountability and strategic responses to sustainability. Stakeholder involvement is a tool used by organizations to help them achieve inclusiveness. To support the achievement of inclusiveness, guidance on how to design and conduct stakeholder engagement was included in the 1999 AA1000 Standard Framework. In 2005, this initial guideline evolved into AA1000 Stakeholder Engagement Standards, the first international standard on stakeholder engagement.

The AA1000SES (2015) was developed through a broad, international and multi-stakeholder process. This process was debated during face-to-face consultations in more than 20 countries with various comprehensive stakeholders. This is the 2nd edition of the AA1000 Stakeholder Engagement Standard. This standard is based on the revised AA1000 AccountAbility Principles Standard (2008).

The main part of AA1000SES 2015 is setting goals, scope (who are intended users), and making it clear that this standard is intended primarily for practitioners and owners of involvement. AA1000SES 2015 has a stakeholder engagement process consisting of four stages:

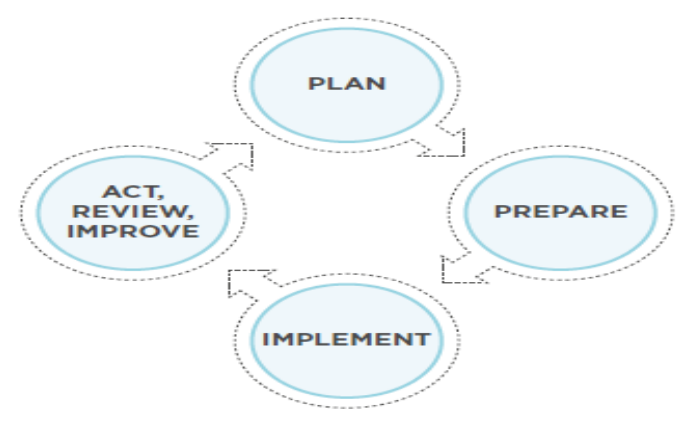

Fig. 1 Stakeholder engagement process

Source: AA1000 Stakeholder Engagement Standard (2015) 


\section{Methodology}

The research approach used is a qualitative approach. The researcher chose to use a qualitative approach because this approach can help researchers achieve their goals in carrying out research by reflecting on the CSR of PT.BNI (Persero) Tbk. The paradigm used by researchers is the interpretive paradigm. Interpretive research seeks to explain the relationship between action and meaning in which interpretation is an active process and creative discipline to ensure the possible meaning of actions and messages (Lannai et al., 2014).

Researchers use the type ofmethod content analysis guided by sustainability accounting (Sukoharsono,, 2010) which aims to answer current and future challenges for social, economic, environmental and spirituality sustainability. The primary data source in this study was through interviews with corporate and community CSR staff and direct observation to review the implementation of the PT.BNI CSR program. While secondary data sources are annual reports and sustainability reports (CSR).

The data analysis technique in sustainability accounting content analysis is to look at the important focus in each dimension based on the data obtained from the results of observations and interviews. In summary and can be described as follows.

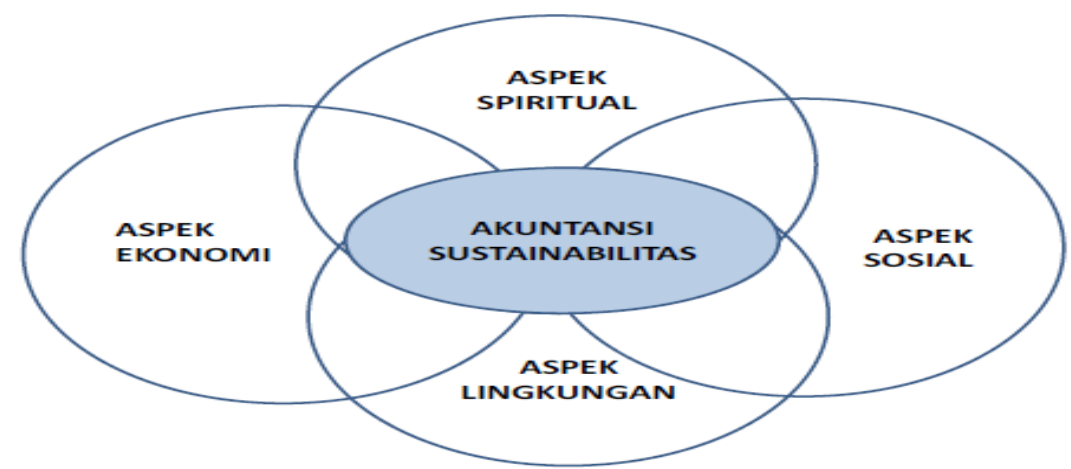

Fig. 2 Accounting for sustainability with 4 organizational aspects: economy, social, environmental and spiritual

Source: Sukoharsono (2010)

The economic dimension focuses on economic growth which is manifested in entrepreneurial activities, agribusiness, joint business activities/ small micro units and the opening of employment opportunities.

The social dimension focuses on economic events that will and have been carried out by the economy that are manifested in training, education, health, social and cultural welfare activities.

The environmental dimension focuses on efforts to restrain activities from the economic dimension so as not to over-exploit the environment. These dimensions of activity include greening, land reclamation, water management, nature preservation, environmental sanitation ecotourism and energy use efficiently.

The spiritual dimension focuses on balancing the meaning of life with oneself, between individuals and groups of organizations. Embodiment of the spiritual dimension through sincere love, sincere love and transcendental awareness. 


\section{Results and Discussion}

Stakeholders are the most important part of a company, BNI bank is a BUMN that cannot be separated from government regulations which are one of its stakeholders. Based on Regulation of the Minister of State-Owned Enterprises No.: Per-05 / MBU / 2007 Article 1 paragraph (6) explains that the BUMN Partnership Program with Small Businesses, hereinafter referred to as the Partnership Program, is a program to increase the ability of small businesses to become resilient and independent through the utilization of funds from the BUMN profits. Whereas in Article 1 paragraph (7), it is explained that the Community Development Program, hereinafter referred to as the BL Program, is an empowerment program for community social conditions by SOEs through the use of funds from the SOE profit section.

From the statement it can be concluded that there are regulations governing the implementation of CSR that must be carried out by Bank BNI as a BUMN. In addition, the stakeholders of Bank BNI are not only the permanent government of employees and the community. Companies need to build value towards stakeholders (value of stakeholders) and value for workers (value of employees) in order to support the stability, growth and going concern of the company. Companies try to find and gain legitimacy, not just to get what they are from stakeholders. One of the company's commitments is to always make improvements to the performance of sustainable development. This means that every year it is necessary to evaluate various social development programs that have been carried out, so that they always strive to find better ways of working. In this connection, the company does not rely solely on the judgment of the company itself. Because the company's experience is still lacking, it will be very valuable if the institutions or researchers involved in the company program provide valuable input and a number of recommendations. These inputs and recommendations are currently being implemented to improve the performance of sustainable development carried out by the company.

\section{Community Engagement in AA 1000}

Stakeholder engagement is the process used by the organization to engage relevant stakeholders for clear objectives to achieve agreed outcomes. It is now also recognized as a fundamental accountability mechanism, because it requires organizations to involve stakeholders in identifying, understanding and responding to issues and ongoing concerns, and to report, explain and answer to stakeholders for decisions, actions and performance.

The AA1000 standard for stakeholder engagement is also a good initiative in this field. The main focus of the AA1000 guideline is to help organizations integrate stakeholder involvement in the development of organizational strategies and operational activities. This consists of all information that can lead to achieving good stakeholder relations in increasing monetary value by forming a good image in the community.

This AA1000SES guideline extracts ideas and processes from various sources, and is intended to be suggestive, not prescriptive. Every company has a unique quality and situation that will affect how a company analyzes its social responsibility. Every company will differ in its awareness of CSR issues and how much work has been done to implement the CSR approach, as well as BNI. There is considerable value in continuing the systematic implementation of CSR - in line with the company's mission, sensitive to business culture, environment and risk profile. CSR is not only good for the community but also makes a profit for the business too.

The AA1000SES guideline proposes an implementation framework consisting of four scopes as follows: 
Table 1 Analysis of the process community engagement

\begin{tabular}{|c|c|c|}
\hline Plan & $\begin{array}{l}\text { Conducting CSR } \\
\text { assessments }\end{array}$ & 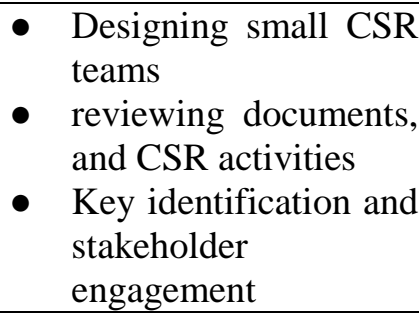 \\
\hline Prepare & Developing CSR Strategies & 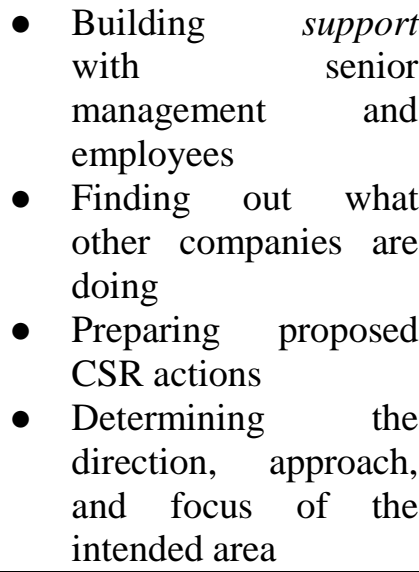 \\
\hline Implement & $\begin{array}{l}\text { Commitment to } \\
\text { implementing CSR }\end{array}$ & 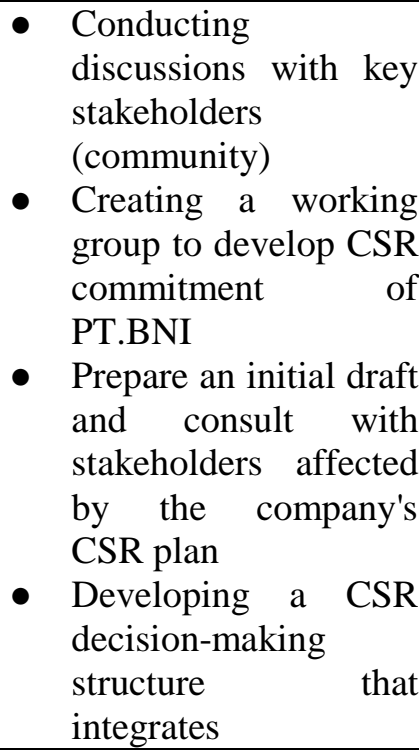 \\
\hline Act, Review, Improve & $\begin{array}{l}\text { Verification, Progress and } \\
\text { Evaluation Reporting }\end{array}$ & 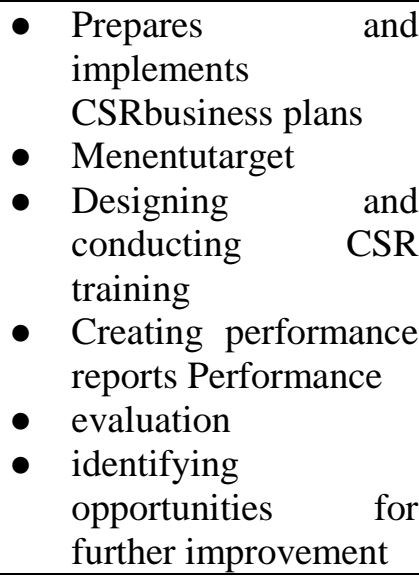 \\
\hline
\end{tabular}




\begin{aligned} & \hline$\bullet$ Making internal and \\ & external \\ & communication plans \\ & \hline\end{aligned}

Source: Results of data processing (2018)

\section{CSR}

Community welfare is very important for the sustainability of the company's operational activities. The Company considers it very necessary to take responsibility for the community. This is in line with BNI's fourth mission of increasing environmental and social awareness and responsibility.

The implementation of corporate social responsibility (CSR) is a moral responsibility to stakeholders. BNI is committed that with or without legal regulations, the company always upholds morality. Thus, the parameter of success is to prioritize moral and ethical principles, namely achieving the best results without harming other groups of people.

The results of the study reflect the meaning of sustanability accounting (environmental dimensions), for the company to carry out CSR activities in the environmental field is an obligation that cannot be negotiated. The work culture value of PT.BNI is one of which provides the best service through strategic, disciplined, consistent and responsible partnerships. Meaning of accounting sustainability (social dimension), related to economic, social, and environmental events that exist in the scope of the company there are differences in addressing the needs of the community. Comparison with other organizations, BNI comes to places that are considered appropriate to provide assistance for the implementation of CSR programs, while other companies only monitor not take action. For example, during a visit by the Minister of Agriculture to Lumajang to see banana plantation centers many banks / organizations were present. However, only BNI is brave and serious in following up the village as a partner of the company.

BNI believes that companies that work by putting forward moral and ethical principles will provide good benefits to society. The implementation of CSR is one form of BNI's social performance and investment to the community. Through the implementation of a planned, well-targeted, transparent and sustainable CSR program, BNI wants to create benefits for the company's presence through efforts to improve the living standards and welfare of the Indonesian people as a whole.

Meaning of Sustanability Accounting (Economic Dimension) BNI applies corporate social responsibility with a focus on PKBL. Through the PKBL mechanism, BNI seeks to empower the community and encourage populist economic growth not only through grants but also through the distribution of soft loans. BNI's PKBL is planned, targeted, transparent and sustainable so that BNI has a role in improving the quality of life of the Indonesian people as well as equitable development through expanding employment opportunities and business opportunities. Furthermore, PKBL mandated for stateowned companies is part of a concerted effort implemented consistently by BNI to ensure the sustainability of its existence as a business entity. PKBL in BNI is carried out by the Corporate Communication and Secretariat Division which is directly supervised by the President Director.

The partnership program activities are directed to small entrepreneurs through low-interest partnership lending. This activity aims to improve capabilities and empower them to become strong and independent entrepreneurs. BNI fostered partners are micro entrepreneurs who do not know banking technically because of limited access to loans from banks. Micro business actors are engaged in various formal and non-formal economic sectors, but have a strategic role in the economy of the real sector and it has been proven that the micro segment is relatively more resilient to the economic crisis. BNI fostered 
partners are expected to increase business activities, business capital, entrepreneurial spirit, access to banking, business administration, product quality and marketing reach.

The meaning of Sustanability Accounting (Spiritual Dimension), related to the spirituality of PT.BNI does not record the spiritual aspects in the description of company reports. But what PT.BNI does is carry out social responsibility activities honestly open to the community, sincere, and sincere with the risks that exist in the future. BNI believes that it is able to build good relationships through the hope that is offered in a joint prayer for the welfare of the community and survival in the future.

\section{Conclusion and Recommendation}

This research was conducted to reflect the CSR of PT. BNI is related to Community Engagement. Based on the results of the analysis and discussion of the research, some conclusions were obtained. The first is the implementation of corporate social responsibility (CSR) for stakeholders (stakeholders) through partnership and community development programs. The informants realized that community involvement had a good impact on the welfare of the community and the survival of PT. BNI. The CSR activities in Kampoeng BNI are aimed at increasing capacity and empowering the community to become strong and independent entrepreneurs.

Suggestions for future researchers are expected to apply sustainability accounting concepts with a spirituality dimension so that there is a balance between the meaning of life to self, between individuals and groups of organizations, because this dimension is difficult to discuss because the reflection of spirituality of each individual is different.

\section{References}

AA1000 Stakeholder Engagement Standard (SES). (2015). Available at http://www.accountability.org

Freeman, R. Edward. (1994). Strategic Management: A stakeholder approach. Boston. Pitman..

Ghozali, I and Anis, C. (2007). Accounting Theory. Undip Publishing Agency, Semarang

Harahap, Sofian S. (2006). Revised Edition Accounting Theory. Jakarta: PT Raja Grafindo Persada.

Kasali, R. (2005). Public Relations Management. Grafiti, Jakarta.

Lannai, D., M. Sudarma, G. Irianto, and U. Ludigdo. (2014). "Phenomenology Study about Meaning at Indonesia's Foundation Performance (Case Studies at Endowments Foundation of Indonesian Muslim University)." International Journal of Business and Management Invention, 3(5): 8-16.

Lin. Philip T. et al. (2014). Corporate Governance and Community Engagement: Evidence from the Australian mining companies. Journal of Resources Policy 43 (2015) 28-39.

Moir, L. (2001). "What Do We Mean by Corporate Social Responsibility? "Corporate governance Journal, 1(2): 16-22.

Moravcikova et al. (2015). CSR Reporting as an Important Tool of CSR Communication. Procedia Economics and Finance, (26): 332-338. 
Government of Indonesia. (2007). Law Number 40 of 2007 Concerning Limited Liability Companies.

Sukoharsono, Eko Ganis. (2007). Green Accounting in Indonesia: Accountability and Environmental issues. The International Journal of Accounting and Business Society, 15(1): 23-66.

Sukoharsono, Eko Ganis. (2010). Social and Environmental Accounting Metamorphosis: Construct Sustainability Accounting with a Spiritual Dimension. The paper is presented at the Inauguration of Brawijaya University Professor. Malang.

Wibisono, Y. (2007). Concept and Application of CSR. Gresik: Fascho Publishing. East Java.

\section{Copyrights}

Copyright for this article is retained by the author(s), with first publication rights granted to the journal.

This is an open-access article distributed under the terms and conditions of the Creative Commons Attribution license (http://creativecommons.org/licenses/by/4.0/). 